\title{
ANALISIS DAERAH PENANGKAPAN IKAN TUNA SIRIP KUNING Thunnus albacares DI PERAIRAN SUMATERA BARAT BERDASARKAN MODEL GAM
}

\section{FISHING GROUND ANALYSIS OF YELLOWFIN TUNA Thunnus albacares IN WEST- SUMATERA WATERS BASED ON GAM MODEL}

\author{
Emma Suri Y. Siregar ${ }^{1 *}$, Vincentius P. Siregar ${ }^{2}$, dan Syamsul B. Agus ${ }^{2}$ \\ ${ }^{1}$ Departemen Teknologi Kelautan, Sekolah Pascasarjana, IPB, Bogor \\ ${ }^{2}$ Departemen Ilmu dan Teknologi Kelautan, FPIK-IPB, Bogor \\ *E-mail: emmasuriyantisiregar@gmail.com
}

\begin{abstract}
The utilization of Generalized Additive Models (GAMs) it is common to predict the fishing ground in Indonesian sea territories with high accuracy. This research aims to predict the fishing ground of yellowfin tuna using GAM. The data used in this research is tuna fishing data from logbook of Bungus Ocean Fishing Port and oceanography data. The analysis of fish abundance was expressed in the value of hook rate tuna longline. Hook rate is the stock density index. In modeling, the dataset was divided into 2 sections: training data used for model formation and evaluation data used to validate predicted results from the model. In this study, 2015 data was used as the training data and data in 2016 was used as the evaluation data. The results showed that, the prediction had generated a total of 14 models through GAMs statistical approach based on oceanographic parameters. Model SST+Salinity $+S S H+C h l-a$ was found the best with the smallest AIC value of 658.1 and the largest deviance value of $56.9 \%$. The deviance value indicated that the GAM equation could explain $56.9 \%$ of the hook rate data. According to the GAM model, potential fishing ground in 2016 were on Siberut and Sipora Islands.
\end{abstract}

Keywords : generalized additive model, Indian ocean, remote sensing

\begin{abstract}
ABSTRAK
Pengunaan Generalized Additive Model (GAM) sudah umum digunakan di beberapa wilayah laut Indonesia dengan tingkat akurasi yang lebih baik. Tujuan dari penelitian adalah untuk memprediksi daerah penangkapan ikan tuna sirip kuning melalui pendekatan statistik Generalized Additive Model (GAM). Data yang digunakan dalam penelitian ini berupa data penangkapan ikan tuna sirip kuning yang didapatkan dari logbook Pelabuhan Perikanan Samudera Bungus dan data oseanografi berupa data suhu permukaan laut, klorofil-a, salinitas dan tinggi muka laut. Analisis kelimpahan ikan dinyatakan dalam nilai laju pancing (hook rate) tuna longline. Laju tangkap merupakan indeks kepadatan stok. Didalam pemodelan, dataset dibagi menjadi 2 bagian yaitu training data yang digunakan untuk pembentukan model dan evaluation data digunakan untuk memvalidasi hasil prediksi dari pemodelan. Pada penelitian ini, data tahun 2015 digunakan sebagai training data dan data tahun 2016 digunakan sebagai evaluation data. Hasil penelitian menunjukkan bahwa, sebanyak 14 model prediksi telah dihasilkan melalui pendekatan model GAM berdasarkan parameter oseanografi. Model variabel SPL+Salinitas+TML+Chl-a merupakan yang terbaik dengan nilai AIC terkecil yaitu sebesar 658,1 dan nilai deviance terbesar yaitu 56,9\%. Nilai deviance memberikan pengertian model GAM tersebut dapat menjelaskan data hook rate sebesar $56,9 \%$. Berdasarkan model GAM, daerah penangkapan ikan yang potensial pada tahun 2016 terdapat pada perairan Pulau Siberut dan Sipora.
\end{abstract}

Kata kunci: generalized additive model, samudera Hindia, penginderaan jauh 


\section{PENDAHULUAN}

Perairan Sumatera bagian barat merupakan salah satu perairan yang produktif dibidang perikanannya. Aktifitas perikanan tuna longline di Samudera Hindia semakin meningkat dalam mengeksploitasi sumberdaya tuna dikarenakan meningkatnya kebutuhan manusia. Berdasarkan data stastistik perikanan Pelabuhan Perikanan Samudera (PPS) Bungus, jumlah kapal tuna longline meningkat dari tahun ke tahun, hal itu terlihat dengan meningkatnya jumlah kapal tuna longline yang berlabuh di PPS Bungus, dimana kunjungan tahun 2012 sebanyak 3.165 kali, 2013 (2.452 kali), 2014 (3.196 kali), 2015 (4.432 kali) dan 2016 (4.188 kali). Salah satu jenis ikan tuna yang tertangkap paling banyak adalah ikan tuna sirip kuning (Thunnus albacares) yang merupakan salah satu sumberdaya ikan unggulan yang terdapat di Provinsi Sumatera Barat dengan produksi tangkapan 580,03 ton pada tahun 2012, 2013 (676,70 ton), 2014 (1.355,93 ton), 2015 (420,41 ton) dan 2016 (319,58 ton) (PPS, 2016). Ikan tuna sirip kuning (Thunnus albacares) tergolong ikan pelagis besar yang banyak ditangkap oleh nelayan di Indonesia. Ikan tuna jenis ini memiliki nilai ekspor yang tinggi yang dapat menunjang pertumbuhan ekonomi dan devisa bagi Negara (Kantun dan Mallawa, 2015).

Salah satu kendala yang dihadapi oleh nelayan-nelayan yang menangkap ikan di Samudera Hindia adalah keterbatasan pengetahuan dalam penentuan lokasi pada penangkapan yang tepat atau menentukan daerah penangkapan ikan yang potensial. Salah satu upaya untuk dapat memperoleh informasi tentang potensi sumberdaya wilayah pesisir dan lautan dalam rangka untuk mengoptimalkan pengelolaan wilayah pesisir dan lautan adalah penggunaan teknologi pengindraan jauh dan sistem informasi geografis (SIG).

Pendugaan daerah penangkapan ikan dapat dilakukan melalui berbagai pendekatan yang pada prinsipnya berusaha mencari keterkaitan dan kesesuaian parameter oseanografi dengan keberadaan gerombolan ikan. Saitoh dan Saitoh (2008) memetakan daerah penangkapan ikan sardine di perairan Jepang menggunakan multi sensor satelit melalui pendekatan sistem informasi geografis. Sama halnya dengan yang dilakukan oleh Siregar dan Hariyadi (2011) di perairan Selat Bali. Namun demikian, umumnya hubungan antara kelimpahan sumberdaya perikanan dengan dinamika faktor lingkungannya tidak linear sehingga pendekatan statistik lebih berkembang dan banyak digunakan (Zuur et al., 2009).

Sukresno et al. (2015) memprediksi sebaran spasial tuna di Samudera Hindia menggunakan rumus pendekatan statistik polinomial regresi berdasarkan parameter suhu perairan. Dari berbagai pendekatan statistik yang ada, generalized additive models (GAMs) lebih banyak digunakan untuk pemodelan habitat suatu jenis ikan karena lebih mampu mengakomodasi hubungan yang tidak linear tersebut (Valavanis et al., 2008).

Generalized Additive Models (GAMs) pertama kali dikembangkan oleh Hastie dan Tibshirani pada tahun 1986 (Hastie dan Tibshirani, 1990). Pengunaan model GAM untuk pendugaan daerah penangkapan sudah umum digunakan, seperti Sardina pilchardus (Giannoulaki et al., 2011), swordfish (Chang et al., 2012), Thymallus thymallus L (Fukuda et al., 2013), sumberdaya perikanan di Laut Arab (Solanki et al., 2016), Rastrelliger kanagurta (Nurdin et al., 2017) dan Thunnus albacares (Rajapaksha et al., 2010; Yen et al., 2012). Pengunaan model GAM untuk pendugaan daerah penangkapan ikan tuna telah dilakukan di beberapa wilayah laut Indonesia dengan tingkat akurasi yang lebih baik (Wibawa, 2011; Zainuddin et al., 2013; Susilo dan Wibawa, 2017). Wibawa (2012) memperkenalkan penggunaan GAM untuk mengukur pengaruh variabel oseanografi terhadap distribusi dan kelimpahan fitoplankton. Zainuddin et al. (2016) 
menggunakan GAM untuk memprediksi daerah penangkapan skipjack tuna berdasarkan parameter suhu permukaan laut dan klorofil-a. Namun saat ini belum ada yang mengembangkan metode prediksi daerah penangkapan ikan tuna sirip kuning melalui pendekatan statistik GAM di Perairan Sumatera Barat. Ketersediaan data satelit oseanografi yang bersifat near realtime berpotensi untuk dijadikan sumber data untuk memprediksi daerah penangkapan tuna sirip kuning.

Tujuan dari penelitian ini adalah mengetahui distribusi parameter lingkungan serta kesesuaian daerah penangkapan ikan tuna sirip kuning dan perubahan daerah penangkapan ikan pada musim barat dan musim timur dengan menggunakan model GAM.

\section{METODE PENELITIAN}

\subsection{Waktu dan Tempat}

Penelitian ini dilaksanakan pada bulan Desember 2017 di Pelabuhan Perikanan Samudera (PPS) Bungus Sumatera Barat, kemudian interpretasi dan analisis data dilakukan di tempat Laboratorium Daerah Penangkapan Ikan, Fakultas Perikanan dan Ilmu Kelautan, Universitas Riau, Pekanbaru. Secara geografis lokasi penelitian terletak pada $08^{\circ} \mathrm{LS}-02^{\circ} \mathrm{LU}$ dan $85^{\circ} \mathrm{BT}-104^{\circ} \mathrm{BT}$ (Gambar 1).

\subsection{Alat dan Bahan}

Alat yang digunakan dalam penelitian ini adalah laptop bersistem operasi Windows dan Linux yang dilengkapi perangkat lunak seperti Ferret v6.96 untuk memvisualisasikan data citra satelit dalam bentuk netCDF, SeaWiFS Data Analysis Sistem (SEADAS) 7.3.2 untuk mengekstrak nilai parameter oseanografi dari data satelit, Rstudio 1.1.419 untuk pemodelan GAM dan analisis statistik, serta ArcGIS 10.3 untuk membuat peta lokasi penelitian dan peta daerah potensial penangkapan ikan. Bahan yang digunakan dalam penelitian ini meliputi: data satelit oseanografi berupa data suhu permukaan laut (SPL), klorofil-a (Chl-a), tinggi muka laut (TML) dan salinitas yang didownload dari website http://marine.copernicus.eu/, data penangkapan ikan tuna sirip kuning yang mencakup lokasi penangkapan, hasil tangkapan bulanan tuna (2015-2016) dan kuisioner nelayan.

\subsection{Data Hasil Tangkapan}

Data penangkapan ikan tuna sirip kuning didapatkan dari logbook Pelabuhan Perikanan Samudera (PPS) Bungus, Sumatera Barat. Data yang diperoleh dari kapal tuna longline yang berlabuh di PPS Bungus berupa hasil tangkapan ikan tuna, posisi tertangkapnya ikan tuna tersebut yang meliputi informasi bujur lintangnya, waktu penangkapan dan data informasi seputar kapal tersebut. Sebagai penunjang, informasi seputar daerah penangkapan, jumlah hasil tangkapan ataupun pengoperasian alat tangkap juga dikumpulkan dari nelayannelayan yang sedang bersandar di darmaga pelabuhan melalui wawancara.

\subsection{Data Oseanografi}

Parameter oseanografi menggambarkan kondisi lingkungan pada saat terjadi penangkapan ikan. Data oseanografi diperoleh dari penggabungan data yang terdiri dari; anomali permukaan laut, arus geostropik permukaan, suhu permukaan laut dan pengamatan in-situ yaitu suhu permukaan laut dan salinitas permukaan laut dengan memanfaatkan sensor satelit seperti; Medium Resolution Imaging Spectrometer (MERIS), Moderate Imaging Spectroradiometer (MODIS), Visible Infrared Imaging Radiometer Suite (VIIRS) dan Sea Viewing Wide Field of View Sensor (SeaWiFS) melalui metode statistik. Data yang dihasilkan berupa data suhu permukaan laut (SPL), klorofil-a (Chl-a), salinitas dan tinggi muka laut (TML). Data satelit dari parameter oseanografi (SPL, salinitas dan TML) ini merupakan data Level 4 bulanan dengan resolusi spasial $0,25^{\circ} \times 0,25^{\circ}$, liputan 
data dari tanggal 01-01-2014 - 2018. Sama halnya dengan data Chl-a yang merupakan data Level 4 bulanan, akan tetapi berbeda resolusi yaitu dengan resolusi spasil $4 \mathrm{~km} \mathrm{x}$ $4 \mathrm{~km}$ dengan liputan data dari tanggal 04-091997 - 31-12-2016. Semua data tersebut diperoleh dari website http://marine. copernicus.eu/.

Data parameter di atas, masingmasing diolah dengan menggunakan perangkat lunak Ferret v6.96 dan SeaWiFS Data Analysis Sistem (SEADAS) 7.3.2 yang memiliki fungsi untuk memvisualisasi data citra satelit dan mengekstrak nilai parameter oseanografi yang selanjutnya akan digunakan untuk memprediksi daerah penangkapan ikan dengan mengembangkan pendekatan statistik GAM menggunakan perangkat lunak $R$ language.

\subsection{Analisis Hasil Tangkapan Ikan Tuna}

Analisis kelimpahan ikan dinyatakan dalam nilai laju pancing (hook rate) tuna longline yaitu jumlah tuna tertangkap oleh 100 mata pancing yang dioperasikan dengan persamaan (Nugraha dan Hufiadi, 2012):

$$
\mathbf{L P}=\frac{\mathrm{E}}{P} x 100
$$

Keterangan : LP = laju pancing (hook rate), $\mathrm{E}=$ jumlah tuna tertangkap (ekor), $\mathrm{P}=$ jumlah pancing yang digunakan.

Laju tangkap (hook rate) merupakan indeks kepadatan stok, digunakan untuk mengetahui tingkat eksploitasi sumberdaya perikanan di suatu perairan. Nilai hook rate tersebut kemudian akan dideskripsikan menggunakan grafik berdasarkan musim penangkapannya.

Selain menggunakan data parameter (SPL, Chl-a, TML dan Salinitas), hasil perhitungan hook rate di atas juga digunakan untuk memprediksi daerah penangkapan ikan dengan mengembangkan pendekatan statistik GAM menggunakan perangkat lunak $R$ language.

\subsection{Penentuan Daerah Penangkapan Ikan (DPI) Dengan Model GAM \\ Generalized additive model (GAM)} merupakan salah satu alternatif model statistika apabila tidak ditemukannya hubungan linear antara dua variabel (Zuur et al., 2007) dan (Zuur et al., 2009). Secara umum GAM menggunakan smoothing curve untuk memodelkan hubungan antara hasil tangkapan (variabel respon) dengan variabel osenografi yang dalam hal ini disebut variabel prediksi (Susilo dan Wibawa, 2017). Secara garis besar dapat dikatakan bahwa, GAM digunakan untuk menentukan sifat hubungan antara hasil tangkapan dan variabel lingkungan.

Back-fitting algorithm merupakan algoritma umum yang dapat digunakan dalam membuat model aditif dengan berbagai pemasangan tipe regresi. Penyusunan model GAM menggunakan pustaka $m g c v$ packages pada perangkat lunak R. Pemilihan variabel prediksi yang mempengaruhi daerah penangkapan ikan (DPI) didasarkan pada nilai Akaike's Information Criteria (AIC) terkecil, nilai Cumulative Deviance Explained (CDE) tertinggi dan tingkat signifikansi terbesar setiap model GAM yang terbentuk (Wood, 2006). Adapun persamaan dasar dari model statistik GAM dari mgcv packages "Predict GAM" yaitu:

$$
\begin{aligned}
g(m u i)= & b o+s 1(x 1 i)+s 2(x 2 i)+s 3(x 3 i) \\
& +\ldots s n(x n i) \ldots \ldots \ldots \ldots \ldots \ldots \ldots \ldots \ldots \ldots \ldots \ldots
\end{aligned}
$$

Keterangan: $g$ adalah link function, mui adalah variabel respon, bo adalah model konstan, $x n$ adalah parameter yang dikembangkan dan $s n$ adalah fungsi spline smooth factor setiap variabel prediksi.

Prediktor dianggap signifikan untuk menjelaskan DPI jika penyimpangan (residual) dan Akaike Information Criteria (AIC) menurun dengan setiap penambahan variabel dan probabilitas akhir variabel lebih rendah dari 0,01 ( $\mathrm{P}<0,01)$ (Zainuddin et al., 2008). 
Pemodelan dengan menggunakan GAM, dataset dibagi menjadi 2 (dua) bagian yaitu training data yang digunakan untuk pembentukan model dan evaluation data digunakan untuk memvalidasi hasil prediksi dari pemodelan tersebut. Penelitian ini menggunakan data tahun 2015 digunakan sebagai training data dan data tahun 2016 digunakan sebagai evaluation data.

\section{HASIL DAN PEMBAHASAN}

\subsection{Hasil Tangkapan Ikan Tuna}

Hasil tangkapan pada musim barat tahun 2015 (Gambar 2a) menurun terhitung dari bulan Desember - Januari dengan nilai sebesar $8.859 \mathrm{~kg}$ turun hingga $2.432 \mathrm{~kg}$, kemudian kembali mengalami kenaikan di bulan Februari sebesar $3.439 \mathrm{~kg}$. Berbeda dengan musim barat tahun 2016 (Gambar 2b), hasil tangkapan mengalami penurunan yang tidak relatif besar terhitung dari bulan Desember-Januari dengan nilai sebesar 3.172 $\mathrm{kg}$ turun hingga $2.556 \mathrm{~kg}$ dan kemudian naik di bulan Februari sebesar $3.846 \mathrm{~kg}$.

Jika ditinjau dari hook rate longline pada musim barat tahun 2015, mengalami penurunan yang relatif besar yang disebabkan oleh menurunnya hasil tangkapan di bulan Desember $(0,85)$, kemudian meningkat kembali di bulan Februari $(0,10)$. Sama halnya dengan hook rate di tahun 2016, menurun dari bulan Desember $(0,15)$ hingga Januari $(0,8)$, kemudian meningkat pada bulan Januari dan kemudian meningkat kembali di bulan Februari menjadi $(0,11)$.

Hasil tangkapan pada musim timur tahun 2015 (Gambar 2c) tertinggi terjadi pada bulan Juli yaitu sebesar $7.490 \mathrm{~kg}$ dengan hook rate 0,15 dan tahun 2016 (Gambar 2d) terjadi pada bulan Agustus yaitu $5.177 \mathrm{~kg}$ dengan hook rate 0,11 . Hasil tangkapan bulan Juni (2015) dengan Juni (2016) mengalami kenaikan sebesar $749 \mathrm{~kg}$ hingga $3.769 \mathrm{~kg}$, tetapi berbeda dengan bulan Juli-Agustus (2015) dan Juli-Agustus (2016) mengalami penurunan.

Penurunan dari hasil tangkapan disebabkan oleh sedikitnya kapal tuna longline yang melakukan penangkapan ikan, dapat dilihat dari sedikitnya spot penangkapan ikan yang ditemukan pada musim timur ini.

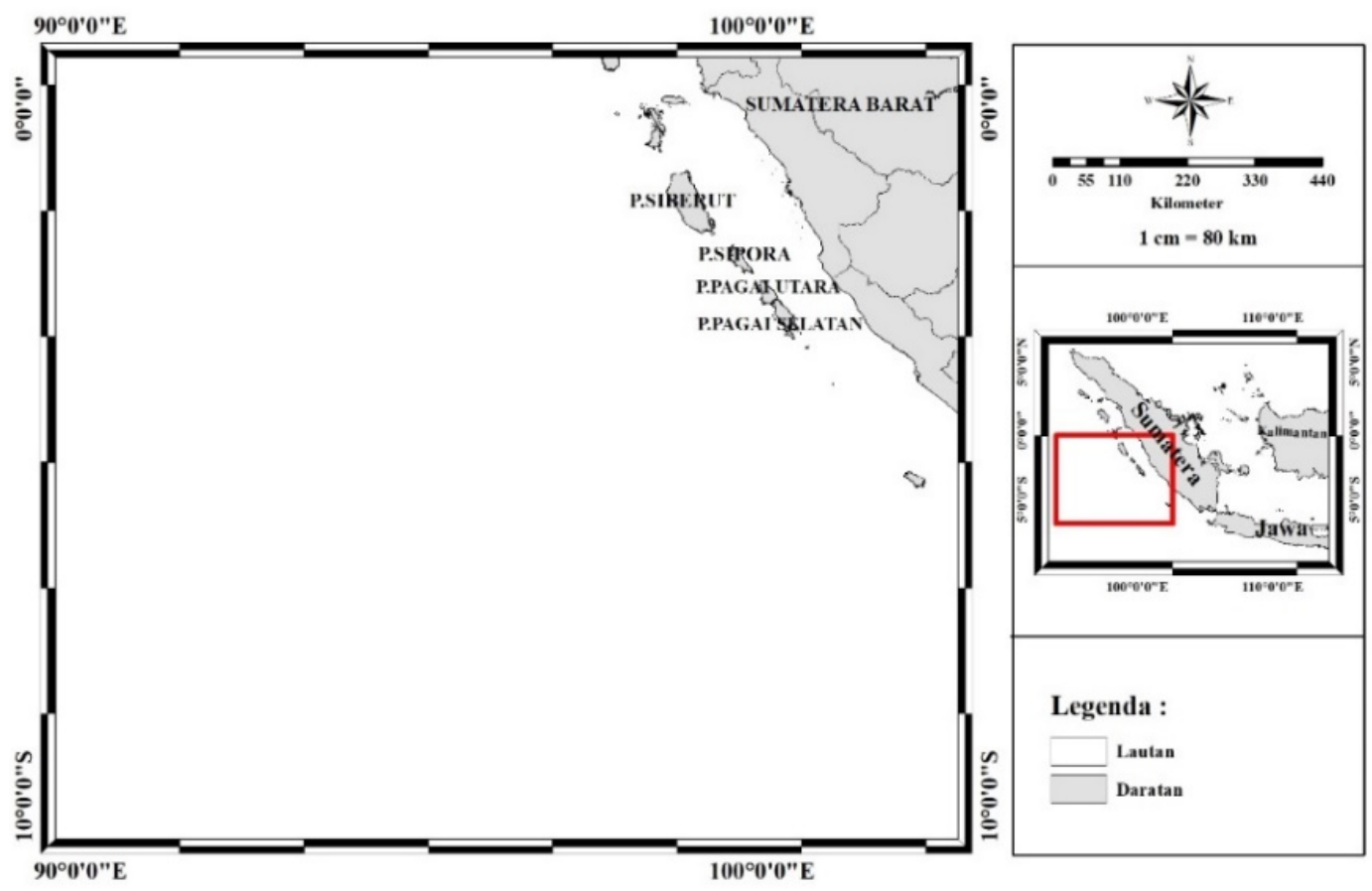

Gambar 1. Lokasi penelitian. 


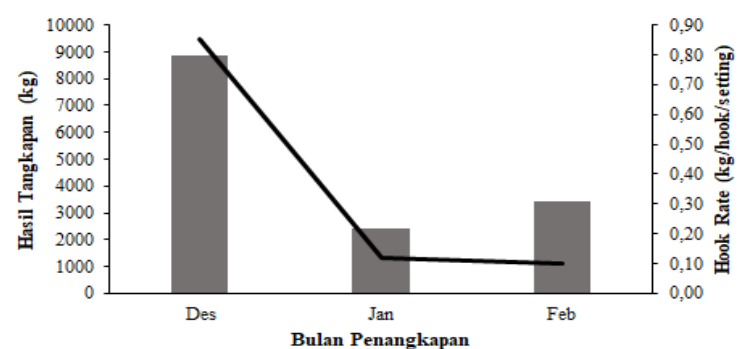

a

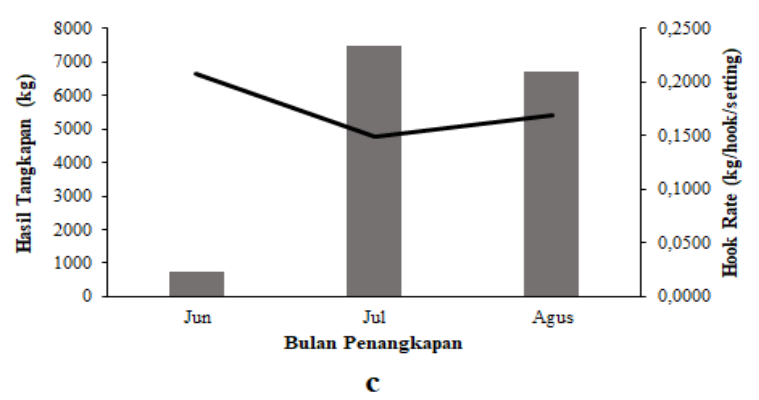

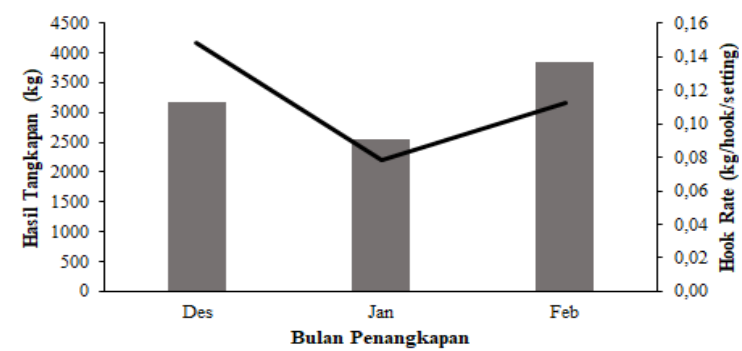

b

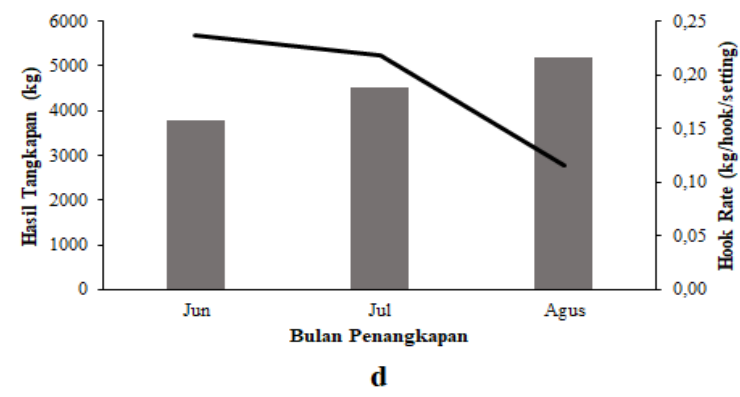

Gambar 2. Hook rate tuna longline dan hasil tangkapan musim barat tahun 2015 (a), 2016 (b) dan musim timur tahun 2015 (c), 2016 (d).

\subsection{Parameter Oseanografi}

\subsubsection{Suhu Permukaan Laut (SPL) Musim Barat dan Musim Timur}

Tahun 2015-2016

Suhu pada musim barat lebih hangat dibandingkan musim timur (Gambar 3). Di antara kedua tahun ini, suhu pada tahun 2016 cenderung lebih hangat. Perbedaan suhu di antara kedua tahun ini disebabkan oleh pengaruh tingginya curah hujan ataupun sedikitnya intensitas matahari yang menyebabkan tinggi rendahnya suhu pada kedua musim ini.

Hasil penelitian ini kemudian diperkuat oleh pendapat Martono et al. (2008), bahwa pada musim barat sebaran SPL di Samudera Hindia relatif hangat, dimana di bagian selatan SPL lebih dingin sehingga arus ekuator utara dan selatan menguat ke arah barat.

Penelitian ini, ikan rata-rata tertangkap pada suhu $29,40^{\circ} \mathrm{C}-29,50^{\circ} \mathrm{C}$, dimana Nontji (1987) menyatakan bahwa ikan tuna sirip kuning (Thunnus albacares) hidup pada perairan dengan suhu berkisar antara $17^{\circ} \mathrm{C}-31^{\circ} \mathrm{C}$.

\subsubsection{Konsentrasi Chl-a Pada Musim Barat dan Musim Timur Tahun 2015-2016}

Gambar 4 menunjukkan bahwa konsentrasi Chl-a tertinggi terdapat pada musim barat, namun konsentrasi Chl-a lebih tinggi pada tahun 2015. Berdasarkan penyebarannya, ikan rata-rata tertangkap pada kisaran $0,15 \mathrm{mg} / \mathrm{m}^{3}-0,17 \mathrm{mg} / \mathrm{m}^{3}$. Kisaran Chl-a ini tergolong pada kategori rendah, namun dapat diperkirakan bahwa proses rantai makanan memiliki peranan penting pada kondisi ini. Konsentasi klorofila dilautan bervariasi secara vertikal yang dipengaruhi oleh faktor-faktor oseanografi seperti suhu permukaan laut, angin, arus dan lain lain (Parsons et al., 2013).

\subsubsection{Tinggi Muka Laut (TML) pada Musim Barat dan Musim Timur Tahun 2015-2016}

Musim timur memiliki TML yang lebih tinggi dibandingkan musim barat seperti yang ditunjukkan pada Gambar 5, dimana TML tertinggi terdapat pada tahun 2016. TML pada musim timur lebih tinggi 
disebabkan karna tingginya intensitas matahari sehingga salah satu penyebab terjadinya pemanasan global yang menyebabkan bertambahnya pencairan bongkahanbongkahan es di kutub. Pencairan es dikutub akan menyebabkan bertambahnya volume air laut karena masuknya air dari es yang mencair dan ekspansi panas karena meningkatnya suhu air laut sehingga menyebabkan berat jenis air laut menurun dan bertambahnya volume air laut global. Berdasarkan penyebarannya, ikan rata-rata tertangkap pada kisaran $0,51 \mathrm{~cm}-0,59 \mathrm{~cm}$. Kisaran TML yang demikian di perkirakan berpotensi terhadap terjadinya proses upwelling ataupun downwelling yang menyebabkan terjadinya pengadukan massa air laut yang membawa unsur hara (Susanto et al., 2001), sehingga di suatu kondisi perairan tersebut dapat dikatakan sebagai daerah yang subur yang mengindikasikan banyaknya ikan ditemukan didaerah perariran tersebut.

\subsubsection{Salinitas pada Musim Barat dan Musim Timur Tahun 2015-2016}

Salinitas pada musim timur lebih tinggi dibandingkan musim barat, dimana puncak tertinggi dari salinitas tersebut terdapat pada tahun 2016 (Gambar 6). Pamungkas (2012) menyatakan jika konsentrasi larutan tubuh ikan dengan lingkungannya tidak seimbang maka tubuhnya akan mengalami stres dan berakibat pada kematian, penyebabnya karena ikan tidak mampu mengontrol proses osmoregulasi (pengaturan osmosis dalam tubuh ikan). Ikan cenderung memilih medium dengan salinitas yang lebih sesuai dengan tekanan osmotik tubuhnya. Berdasarkan penyebarannya, berdasarkan penelitian ini bahwa ikan tuna rata-rata tertangkap pada kisaran salinitas 33,3 psu - 33,7 psu. Pernyataan tersebut sesuai dengan pernyatan Supadiningsih dan Nurul (2004), bahwa ikan tuna sirip kuning jarang terdapat pada perairan dengan salinitas yang rendah, umumnya ikan tuna dapat tertangkap pada kisaran salinitas antara 32-35 psu.

\subsection{Prediksi DPI Tahun 2016 dengan Model GAM}

Kombinasi persamaan GAM yang terbentuk dari ke empat variabel oseanografi ditampilkan pada Tabel 1. Pemilihan persamaan didasarkan pada nilai Akaike's Information Criteria (AIC) terkecil, Cumulative Deviance Explained (CDE) dan tingkat signifikansi setiap persamaan. Model yang berhasil dikembangkan dalam penelitian ini yaitu sebanyak 14 model dengan pengembangan parameter suhu permukaan laut (SPL), salinitas, tinggi muka laut (TML) dan konsentrasi klorofil-a (Chla).

Beberapa model yang berhasil dibangun dalam penelitian ini, yang memiliki AIC terbesar $(673,9)$ terdapat pada model variabel SPL + TML dan nilai CDE terkecil $(53,7 \%)$ terdapat pada model variabel Salinitas. Jika ditinjau dari keseluruhan model yang ada, bahwa model variabel SPL + Salinitas + TML + Chl-a merupakan yang terbaik dengan nilai AIC terkecil yaitu sebesar 658,1 dan nilai CDE terbesar yaitu $56,9 \%$. Nilai deviance memberikan pengertian model GAM tersebut dapat menjelaskan data hook rate sebesar 56.9\%. Variabel SPL $(\mathrm{p}=0,00163 * *)$ dan Chl-a $(p=0,09021)$ mempunyai kontribusi yang paling besar dibandingkan dengan variabel Salinitas $(p=0,74861)$ dan TML $(p=0,47014)$.

\subsection{Hubungan Antara Tuna Sirip Kuning dan Parameter Oseanografi}

Kurva smoothing (Gambar 7), sumbu $\mathrm{x}$ menunjukkan nilai variabel penjelas dan sumbu y menunjukkan kontribusi yang lebih halus terhadap nilai yang sesuai ataupun yang lebih berperan. Pada garis horizontal merepresentasikan nilai titik data yang diamati. Garis putus-putus menunjukkan selang kepercayaan 95\% untuk masing- 


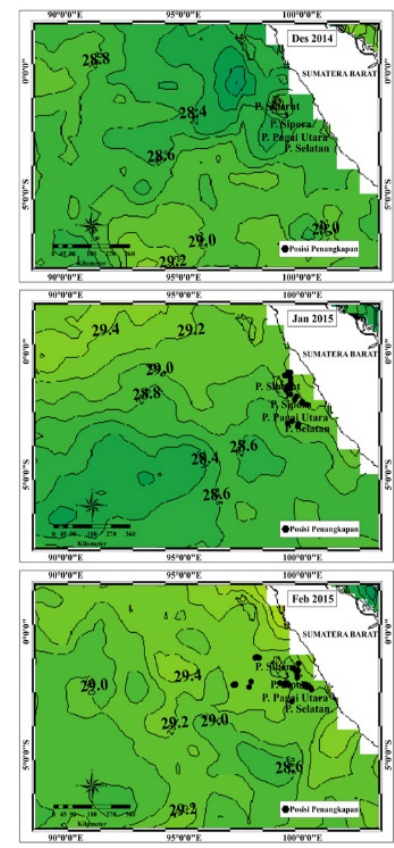

(a)

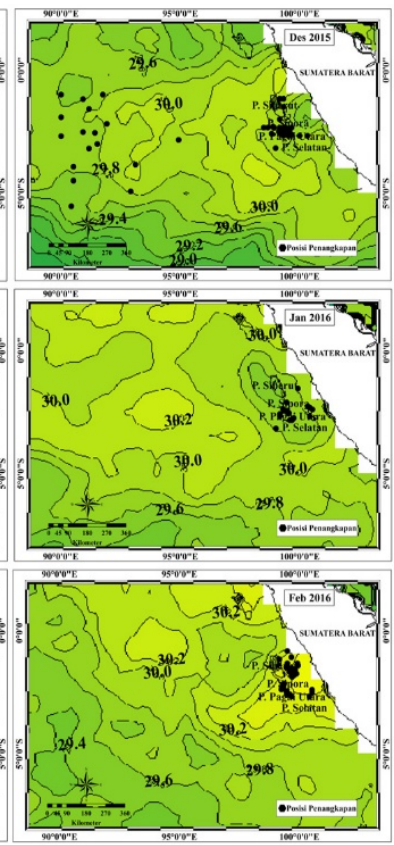

(b)

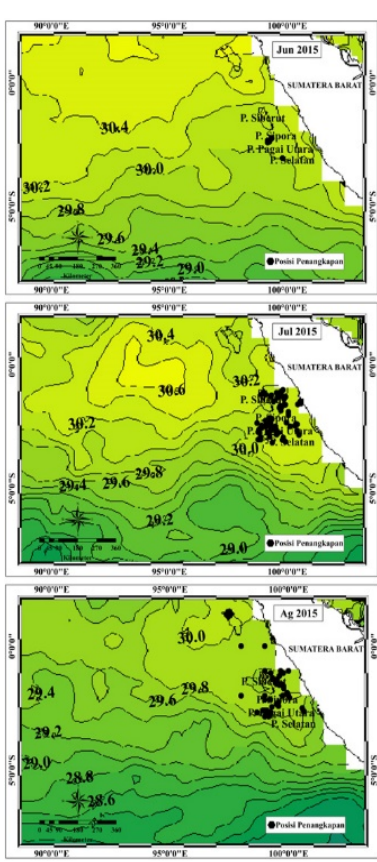

(c)

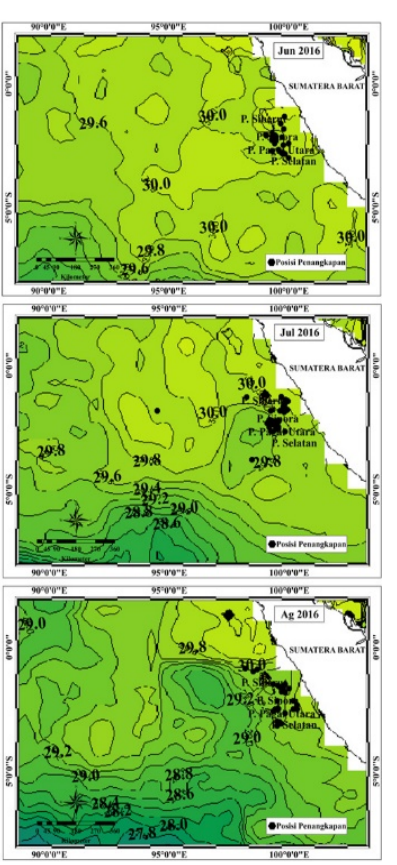

(d)

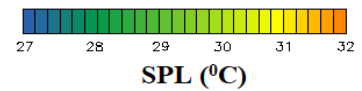

Gambar 3. Sebaran spasial SPL pada musim barat tahun 2015 (a), tahun 2016 (b) dan musim timur tahun 2015 (c), tahun 2016 (d).

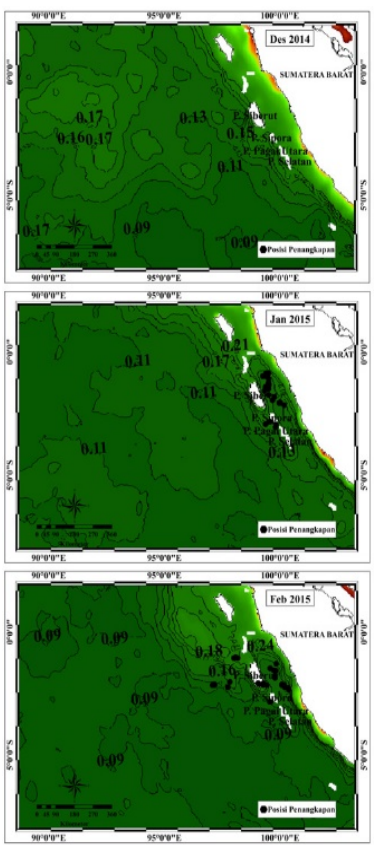

(a)
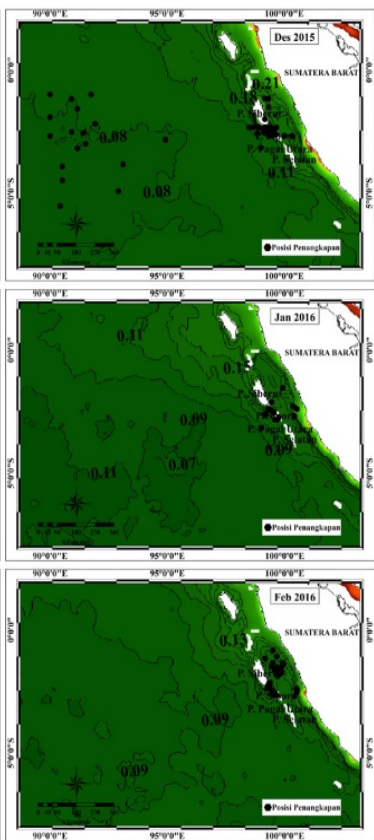

(b)

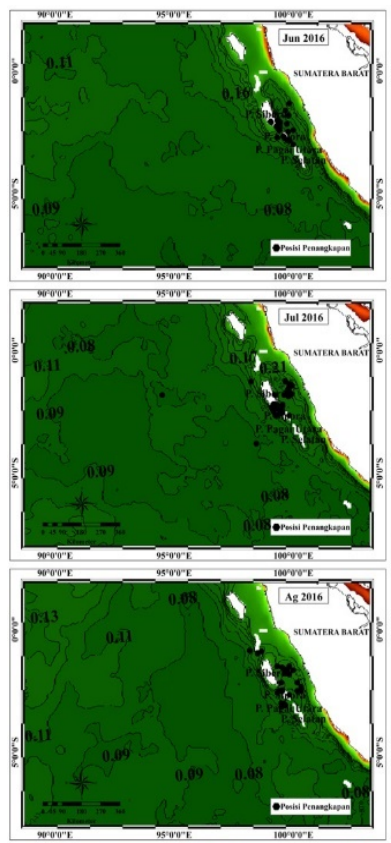

(c)

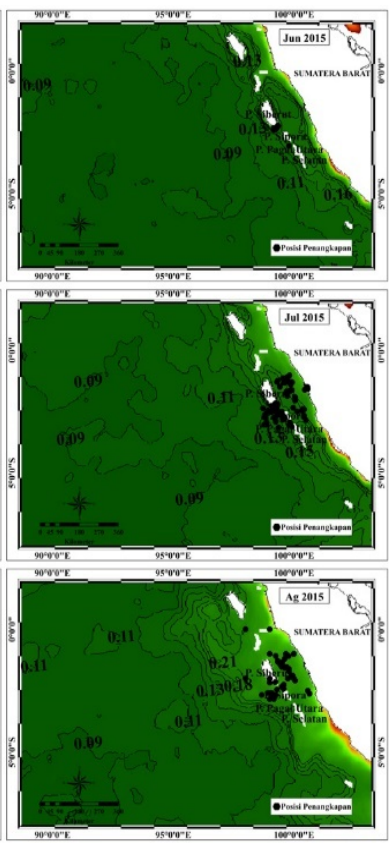

(d)

Gambar 4. Sebaran spasial Chl-a pada musim barat tahun 2015 (a), tahun 2016 (b) dan musim timur tahun 2015 (c), tahun 2016 (d). 


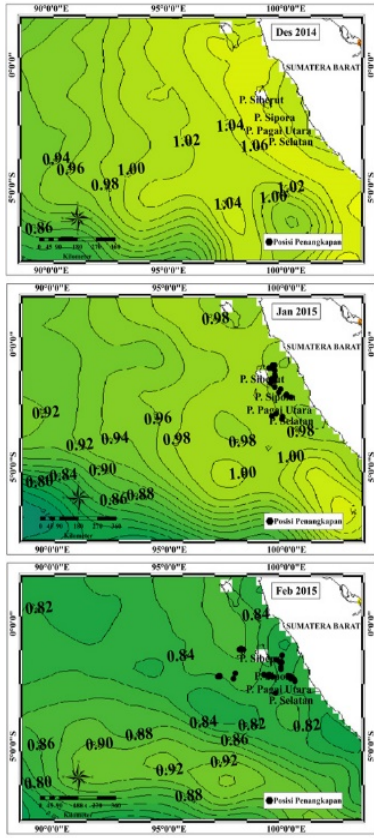

(a)

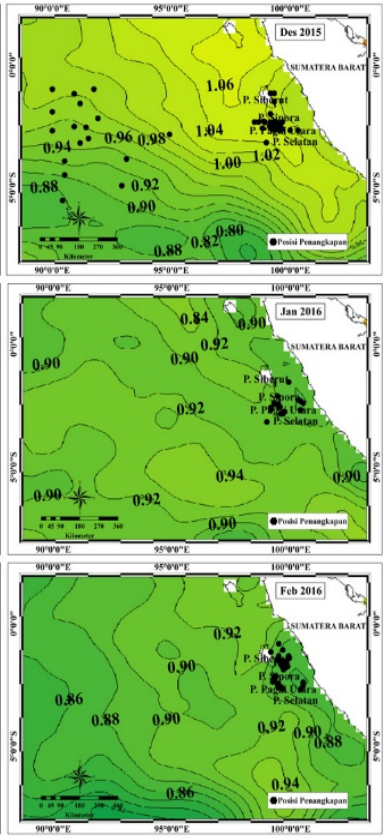

(b)

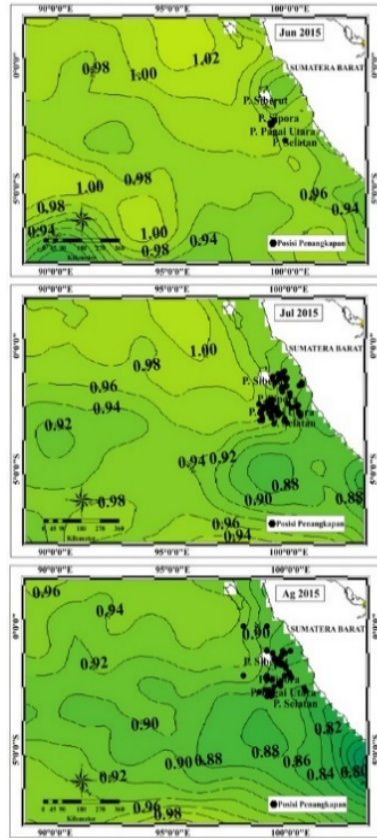

(c)

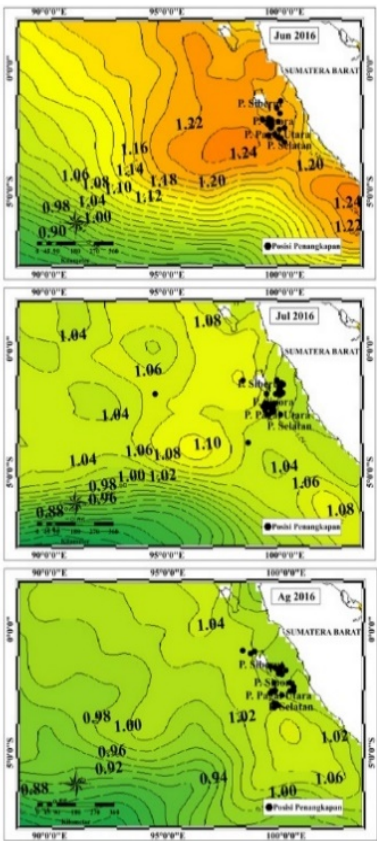

(d)

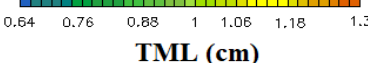

Gambar 5. Sebaran spasial TML pada musim barat tahun 2015 (a), tahun 2016 (b) dan musim timur tahun 2015 (c), tahun 2016 (d).

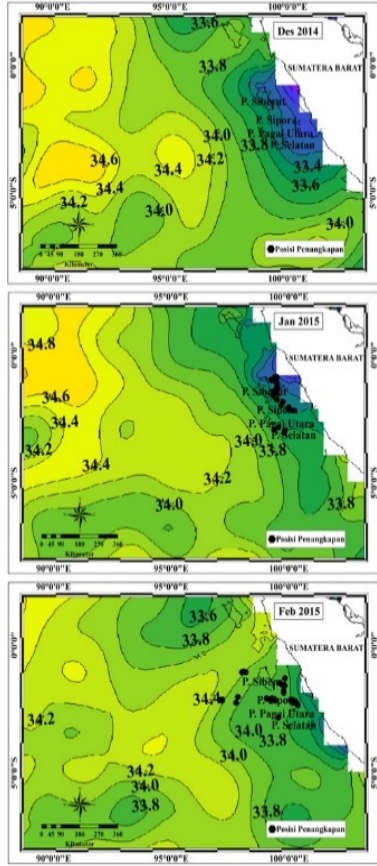

(a)

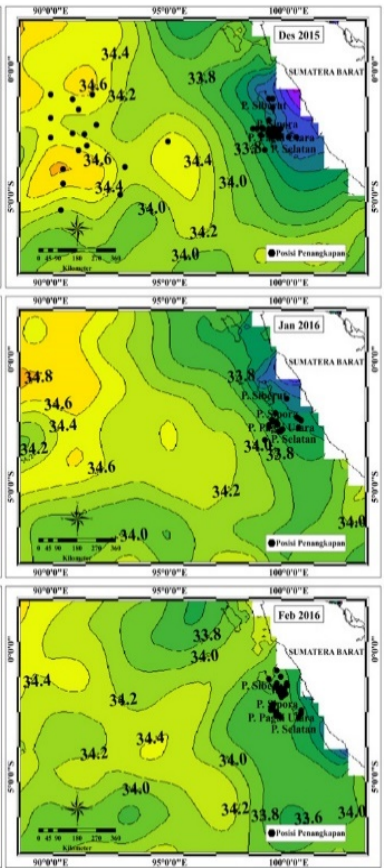

(b)
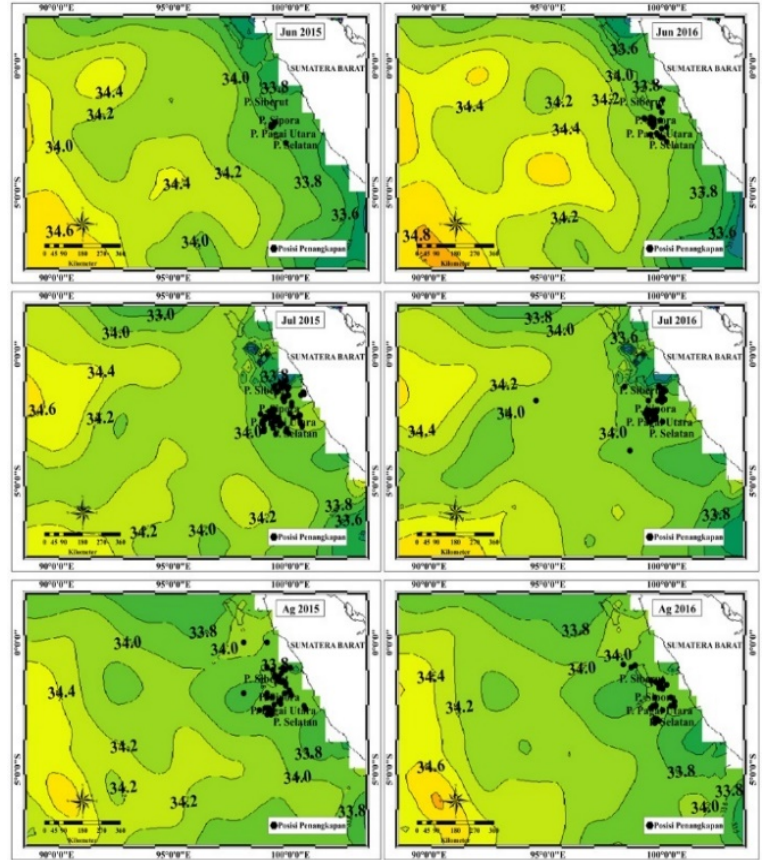

(c)

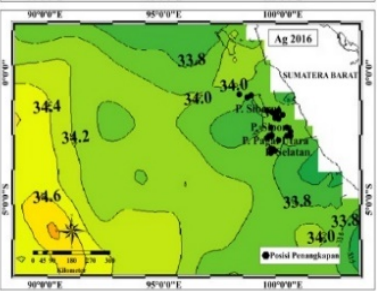

(d)

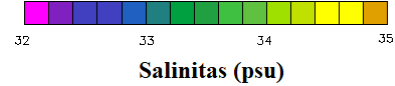

Gambar 6. Sebaran spasial Salinitas pada musim barat tahun 2015 (a), tahun 2016 (b) dan musim timur tahun 2015 (c), tahun 2016 (d). 
masing variabel penduga. Garis horizontal di nol menunjukkan tidak ada pengaruh dari parameter. Persentase nilai lebih tinggi apabila fungsi GAM yang dikembangkan berada di atas sumbu nol yang mengindikasikan bahwa kuatnya pengaruh dari suatu parameter dan jika dibawah sumbu 0 mengindikasikan lemahnya pengaruh suatu parameter terhadap ikan tuna sirip kuning.

Pengaruh antara parameter oseanografi dengan ikan tuna sirip kuning di uraikan pada masing-masing plotan GAM. Hubungan SPL yang paling kuat (tinggi) berkisar antara $29,3^{\circ} \mathrm{C}-29,4^{\circ} \mathrm{C}$, namun yang paling rendah berkisar antara $28,0^{\circ} \mathrm{C}-$ $28,1^{\circ} \mathrm{C}$. Jika dilihat pada Salinitas, hubungan yang paling kuat terdapat pada kisaran 33,0 psu - 33,1 psu dan yang paling rendah berkisar antara 34,0 psu - 34,1 psu. Pada parameter TML, hubungan yang paling kuat berkisar antara $0,49 \mathrm{~cm}-0,50 \mathrm{~cm}$ dan terendah $0,57 \mathrm{~cm}-0,58 \mathrm{~cm}$. Untuk parameter yang terakhir yaitu Chl-a, hubungan yang paling kuat terdapat pada konsentrasi 0,1 $\mathrm{mg} / \mathrm{m}^{3}$ dan yang paling rendah pada konsentrasi $0,3 \mathrm{mg} / \mathrm{m}^{3}$.

Tabel 1. Hasil kombinasi persamaan GAM yang terbentuk tahun 2016.

\begin{tabular}{|c|c|c|c|c|c|}
\hline No. & Model & Variabel & p-value & AIC & $\begin{array}{l}\text { CDE } \\
(\%)\end{array}$ \\
\hline 1. & SPL & SPL & 0,253 & 668,9 & $54,4 \%$ \\
\hline 2. & Salinitas & Salinitas & 0,293 & 673,3 & $53,7 \%$ \\
\hline 3. & TML & TML & $0,0421 *$ & 672,5 & $54,1 \%$ \\
\hline 4. & Chl-a & Chl-a & 0,0834 & 670,4 & $54,8 \%$ \\
\hline 5. & SPL+Salinitas & $\begin{array}{l}\text { SPL } \\
\text { Salinitas }\end{array}$ & $\begin{array}{c}0,00363 \\
* * \\
0,04460 *\end{array}$ & 660,2 & $55,5 \%$ \\
\hline 6. & SPL+TML & $\begin{array}{l}\text { SPL } \\
\text { TML }\end{array}$ & $\begin{array}{c}0,00399 \\
* * \\
0,10515\end{array}$ & 660,7 & $55,6 \%$ \\
\hline 7. & SPL + Chl-a & $\begin{array}{l}\text { SPL } \\
\text { Chl-a }\end{array}$ & $\begin{array}{c}0,00339 \\
* * \\
0,02231 *\end{array}$ & 656,6 & $56,6 \%$ \\
\hline 8. & Salinitas+TML & $\begin{array}{l}\text { Salinitas } \\
\text { TML }\end{array}$ & $\begin{array}{l}0,595 \\
0,340\end{array}$ & 673,9 & $54,5 \%$ \\
\hline 9. & Salinitas + Chl-a & $\begin{array}{l}\text { Salinitas } \\
\text { Chl-a }\end{array}$ & $\begin{array}{l}0,666 \\
0,127\end{array}$ & 672,2 & $54,9 \%$ \\
\hline 10. & $\mathrm{TML}+\mathrm{Chl}-\mathrm{a}$ & $\begin{array}{l}\text { TML } \\
\text { Chl-a }\end{array}$ & $\begin{array}{l}0,2702 \\
0,0759\end{array}$ & 669,5 & $55,7 \%$ \\
\hline 11. & SPL+Salinitas+TML & $\begin{array}{l}\text { SPL } \\
\text { Salinitas } \\
\text { TML }\end{array}$ & $\begin{array}{c}0,00255 \\
* * \\
0,12942 \\
0,15986\end{array}$ & 660,3 & $55,8 \%$ \\
\hline 12. & SPL + Salinitas + Chl-a & $\begin{array}{l}\text { SPL } \\
\text { Salinitas } \\
\text { Chl-a }\end{array}$ & $\begin{array}{c}0,00299 \\
* * \\
0,48920 \\
0,07519\end{array}$ & 658,4 & $56,7 \%$ \\
\hline 13. & Salinitas+TML+Chl-a & $\begin{array}{l}\text { Salinitas } \\
\text { TML } \\
\text { Chl-a }\end{array}$ & $\begin{array}{l}0,8709 \\
0,2815 \\
0,0882 \\
\end{array}$ & 671,4 & $55,9 \%$ \\
\hline
\end{tabular}




\begin{tabular}{|c|c|c|c|c|c|}
\hline No. & Model & Variabel & $\mathrm{p}$-value & AIC & $\begin{array}{c}\text { CDE } \\
(\%)\end{array}$ \\
\hline 14. & $\begin{array}{l}\text { SPL+Salinitas+TML+ } \\
\text { Chl-a }\end{array}$ & $\begin{array}{l}\text { SPL } \\
\text { Salinitas } \\
\text { TML } \\
\text { Chl-a }\end{array}$ & $\begin{array}{c}0,00163 \\
* * \\
0,74861 \\
0,47014 \\
0,09021\end{array}$ & 658,1 & $56,9 \%$ \\
\hline
\end{tabular}

Signif. codes: 0 ‘***’ 0.001 '**’ 0.01 '*’ 0.05 ‘' 0.1 ', 1
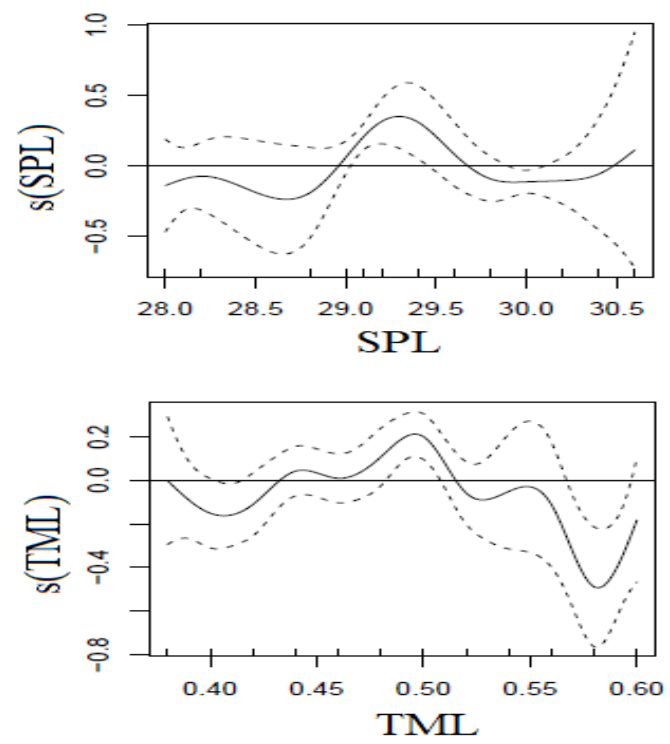
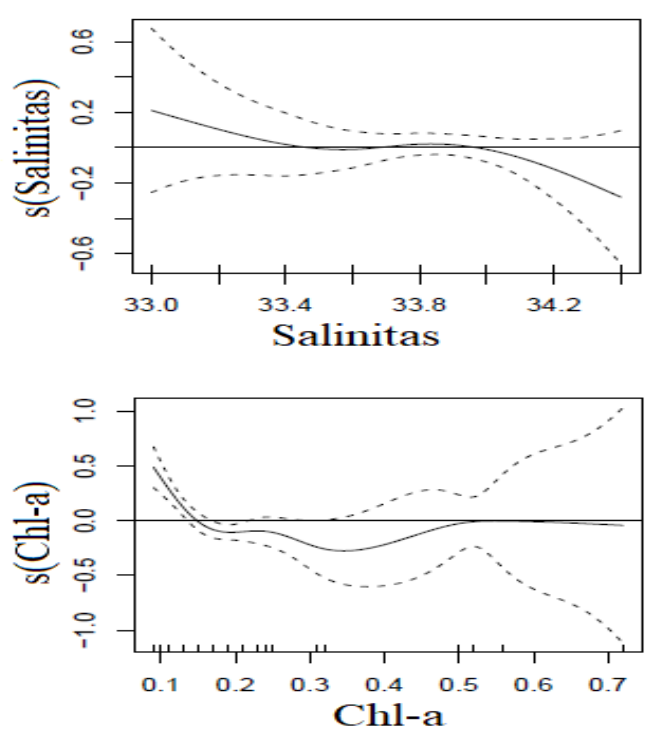

Gambar 7. Kurva smoothing hasil analisis GAM pada setiap variabel prediksi 2016.

\subsection{Hasil Prediksi dan Validasi}

\subsubsection{Prediksi DPI pada Musim Barat}

Most Probable Location (MPL) yang tinggi pada bulan Desember berada di bagian barat hingga timur PPS Bungus, khususnya di perairan Pulau Siberut, Sipora, Pagai Utara dan Pagai Selatan (Gambar 8). Tingginya MPL mengindikasikan bahwa daerah tersebut merupakan daerah penangkapan yang potensial. Daerah penangkapan yang sesuai untuk ikan tuna sirip kuning dipengaruhi oleh perameter lingkungan. SPL pada bagian barat PPS Bungus ini cukup hangat yaitu berkisar antara $28^{\circ} \mathrm{C}-30^{\circ} \mathrm{C}$ yang dapat diartikan bahwa suhu tersebut sangat sesuai dengan tubuh ikan tuna sirip kuning. Nontji (1987) menyatakan bahwa ikan tuna sirip kuning Thunnus albacares hidup pada perairan dengan suhu berkisar antara $17^{\circ} \mathrm{C}-31^{\circ} \mathrm{C}$.
Daerah tersebut ditemukan konsentrasi Chl-a yang tinggi yaitu berkisar antara $0,01 \mathrm{mg} / \mathrm{m}^{3}-1,1 \mathrm{mg} / \mathrm{m}^{3}$. Lumban Gaol et al. (2004) menyatakan klorofil dan suhu permukaan laut merupakan parameter oseanografi yang sangat berperan terhadap variabilitas hasil tangkapan. TML pada bagian barat PPS Bungus ini berkisar antara $0,5 \mathrm{~cm}-0,7 \mathrm{~cm}$ dengan Salinitas $32,8 \mathrm{psu}-$ 33,8 psu. Semua itu diperkuat dengan banyaknya aktivitas penangkapan yang ditemukan di sekitar perairan tersebut.

Most Probable Location (MPL) yang tinggi pada bulan Januari berada di bagian barat PPS Bungus kemudian mengalami pergeseran sehingga didominasi oleh MPL yang rendah. SPL pada daerah ini lebih hangat dibandingkan bulan Desember yaitu berkisar antara $30^{\circ} \mathrm{C}-31^{\circ} \mathrm{C}$. Konsentrasi Chl-a berkisar antara $0,01 \mathrm{mg} / \mathrm{m}^{3}-0,8$ 
$\mathrm{mg} / \mathrm{m}^{3}$, TML $(0,5 \mathrm{~cm}-0,6 \mathrm{~cm})$ dan Salinitas (33,8 psu - 34 psu). Berlandaskan pada kondisi parameter yang demikian, dengan rendahnya nilai MPL di daerah tersebut mengindikasikan bahwa daerah tersebut tidak sesuai dengan kondisi habitat yang disukai oleh ikan tuna sirip kuning. Walaupun di daerah tersebut khususnya disekitar perairan Siberut, Sipora, Pagai Utara dan Pagai Selatan ditemukan penangkapan ikan. Namun penangkapan pada bulan ini tidak sebanyak bulan Desember.

Most Probable Location (MPL) yang tinggi pada bulan Februari berada di bagian barat PPS Bungus, khususnya di sekitar perairan Pulau Siberut ataupun Sipora. SPL pada daerah tersebut berkisar antara $30^{\circ} \mathrm{C}-$ $31,5^{\circ} \mathrm{C}$, Chl-a $\left(0,1 \mathrm{mg} / \mathrm{m}^{3}-0,4 \mathrm{mg} / \mathrm{m}^{3}\right)$, TML $(0,5 \mathrm{~cm}-0,6 \mathrm{~cm})$ dan Salinitas $(33,6$ psu - 34 psu) yang menjelaskan bahwa kondisi parameter tersebut sesuai dengan
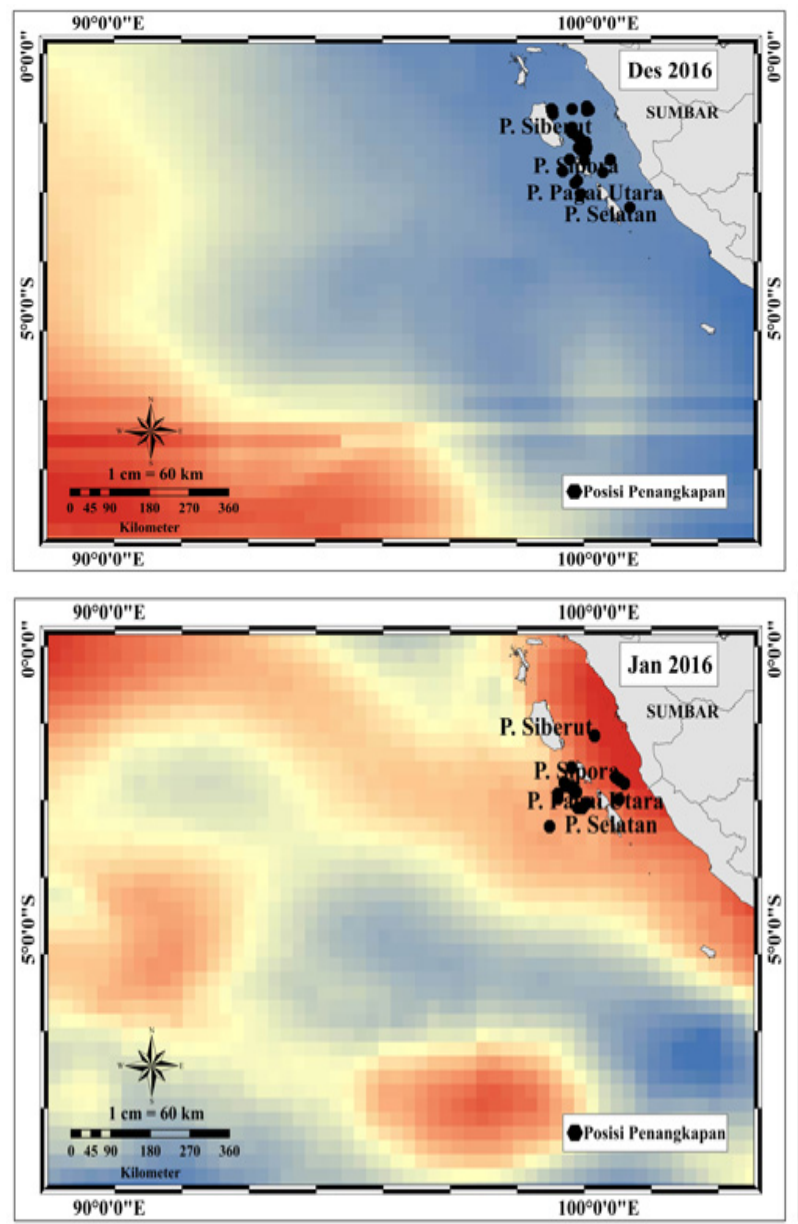

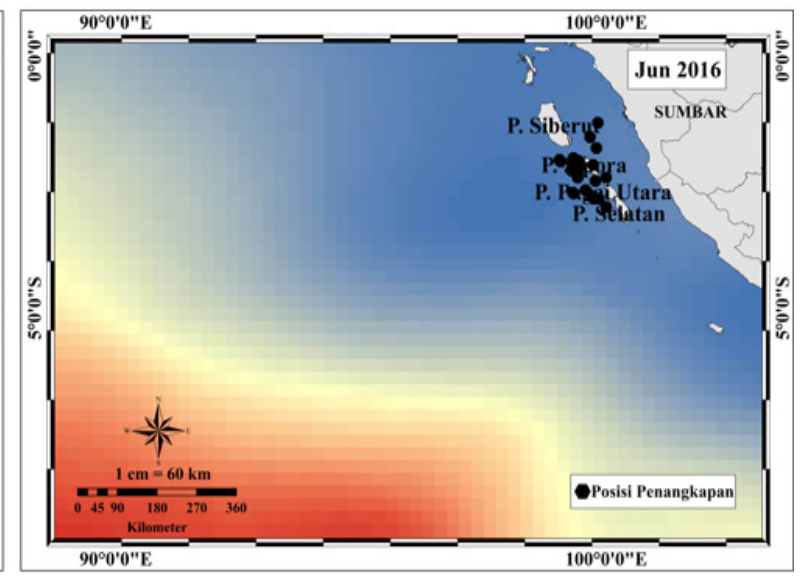

ikan tuna sirip kuning, seperti yang dinyatakan oleh Nontji (1987) bahwa ikan tuna sirip kuning (Thunnus albacares) hidup pada perairan dengan suhu berkisar antara $17^{\circ} \mathrm{C}-31^{\circ} \mathrm{C}$ dan (Dahuri, 2008) menyatakan ikan tuna sirip kuning lebih menyukai hidup disekitar lapisan thermocline dengan kisaran suhu perairan $18^{\circ} \mathrm{C}-31^{\circ} \mathrm{C}$. Jika ditinjau dari Salinitasnya, bahwa ikan tuna sirip kuning jarang terdapat pada perairan dengan salinitas yang rendah, umumnya ikan tuna dapat tertangkap pada kisaran salinitas antara 32-35 psu (Supadiningsih dan Nurul, 2004). Pendapat tersebut di perkuat dengan banyaknya ditemukan penangkapan di perairan tersebut. Berdasarkan pernyataan di atas, daerah penangkapan ikan (DPI) yang tergolong potensial pada musim ini terdapat pada bagian barat PPS Bungus, khususnya pada Pulau Siberut dan Pulau Sipora.

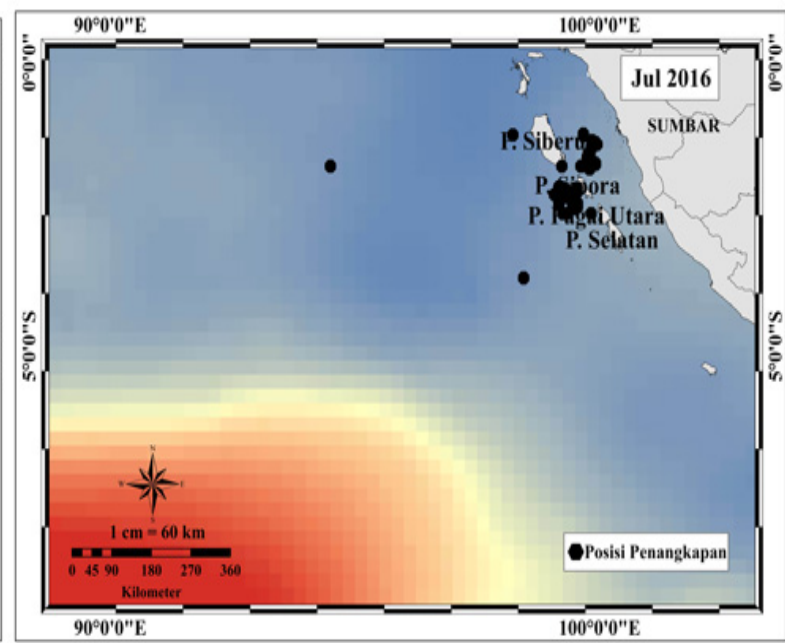




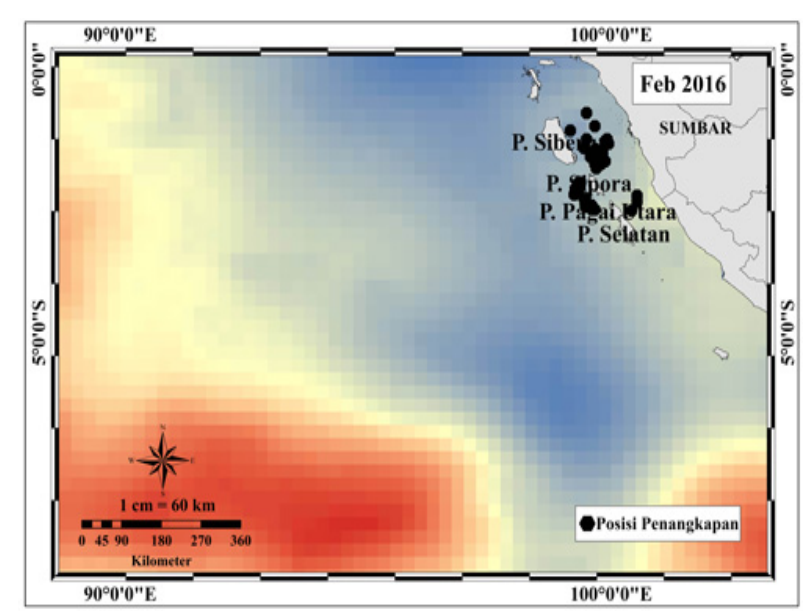

(a)

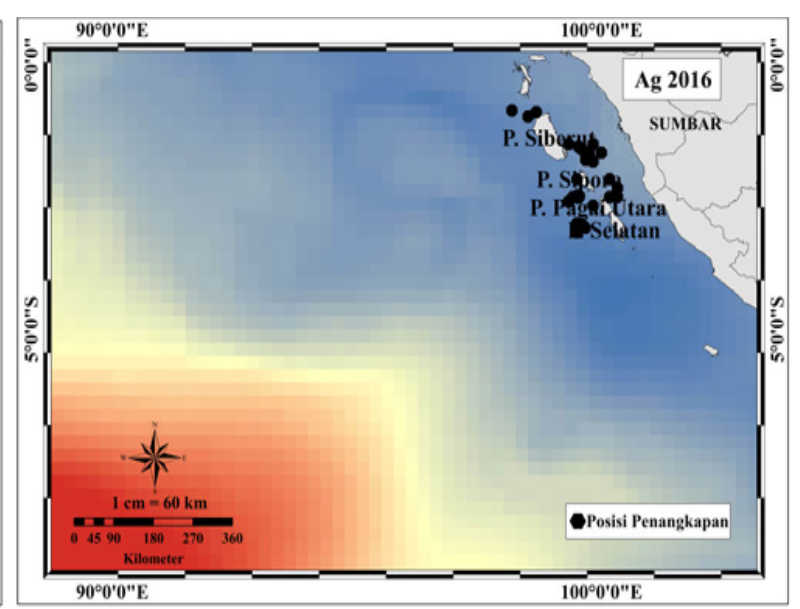

(b)

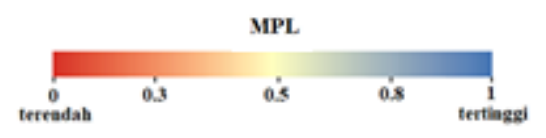

Gambar 8. Distribusi spasial hasil prediksi DPI tuna menggunakan model GAM pada musim barat (a) dan musim timur (a) yang di overlay dengan posisi penangkapan tahun 2016.

\subsubsection{Prediksi DPI pada Musim Timur}

Berdasarkan variasi dari Most

Probable Location (MPL) pada Gambar 8, MPL tertinggi pada bulan Juni terdapat pada bagian barat PPS Bungus terutama pada Pulau Siberut, Sipora, Pagai Utara dan Pagai Selatan. Kondisi parameter menjadi penentu utama tinggi rendahnya MPL. Apabila kondisi tersebut sesuai dengan habitat ikan tuna sirip kuning tentunya akan menyebabkan MPL meningkat.

Bagian barat PPS Bungus ini SPL berkisar antara $30^{\circ} \mathrm{C}-31^{\circ} \mathrm{C}$, Chl-a $(0,3$ $\left.\mathrm{mg} / \mathrm{m}^{3}-1,2 \mathrm{mg} / \mathrm{m}^{3}\right)$, TML $(0,8 \mathrm{~cm}-0,9 \mathrm{~cm})$ dan Salinitas (33,8 psu - 34,4 psu). Namun penangkapan yang paling banyak ditemukan di sekitar Pulau Sipora, Pagai Utara dan Pagai Selatan yang dapat diartikan bahwa daerah tersebut daerah penangkapan ikan yang potensial. Sama halnya dengan MPL pada bulan Juni, pada bulan Juli ini MPL yang tinggi juga berada di bagian barat PPS Bungus, hanya saja sedikit mengalami penurunan. Jika dilihat kondisi parameternya, SPL berkisar antara $29^{\circ} \mathrm{C}-30,5^{\circ} \mathrm{C}$, Chl-a $\left(0,3 \mathrm{mg} / \mathrm{m}^{3}-1,1 \mathrm{mg} / \mathrm{m}^{3}\right)$, TML $(0,6 \mathrm{~cm}-0,7$ $\mathrm{cm})$ dan Salinitas (33,8 psu - 34,0 psu).
Aktivitas penangkapan paling banyak ditemukan di sekitar perairan Siberut dan Sipora.

Most Probable Location (MPL) yang tinggi pada bulan Juni dan Juli berada di bagian barat PPS Bungus. MPL pada bulan ini lebih tinggi dibandingkan bulan Juli dengan SPL $\left(29^{\circ} \mathrm{C}-30^{\circ} \mathrm{C}\right)$, Chl-a $\left(0,3 \mathrm{mg} / \mathrm{m}^{3}\right.$ - $\left.1,2 \mathrm{mg} / \mathrm{m}^{3}\right)$, TML $(0,6 \mathrm{~cm}-0,7 \mathrm{~cm})$ dan Salinitas (34 psu - 34,2 psu). Semua itu diperkuat oleh banyaknya ditemukan penangkapan ikan di sekitar Pulau Siberut, Sipora, Pagai Utara dan Pagai Selatan.

Berdasarkan pernyataan di atas, daerah penangkapan ikan (DPI) yang potensial pada musim ini terdapat pada bagian barat PPS Bungus, khususnya di perairan Pulau Siberut, Sipora, Pagai Utara dan Pagai Selatan.

\section{KESIMPULAN}

Distribusi spasial parameter lingkungan pada musim barat berkisar antara; SPL $\left(28,4^{\circ} \mathrm{C}-30,2^{\circ} \mathrm{C}\right)$, Chl-a $(0,07$ $\left.\mathrm{mg} / \mathrm{m}^{3}-1,5 \mathrm{mg} / \mathrm{m}^{3}\right)$, TML $(0,82 \mathrm{~cm}-1,06$ $\mathrm{cm})$ dan Salinitas $(33,4 \mathrm{psu}-34,8 \mathrm{psu})$ dan 
pada musim timur SPL $\left(28,0^{\circ} \mathrm{C}-30,4^{\circ} \mathrm{C}\right)$, Chl-a $\left(0,08 \mathrm{mg} / \mathrm{m}^{3}-1,5 \mathrm{mg} / \mathrm{m}^{3}\right)$, TML $(0,82$ $\mathrm{cm}-1,24 \mathrm{~cm})$ dan Salinitas (33,0 psu - 34,8 psu). Daerah penangkapan ikan yang potensial pada musim barat dan musim timur terdapat pada bagian barat PPS Bungus.

\section{DAFTAR PUSTAKA}

Chang, Y.J., C.L. Sun, Y. Chen, S.Z. Yeh, and G. Dinardo. 2012. Habitat suitability analysis and identification of potential fishing grounds for swordfish, Xiphias gladius, in the south Atlantic Ocean. Inter. J. Remote Sensing, 33:7523-7541. http://dx.doi. org/10.1080/01431161.2012.685980.

Dahuri, R. 2008. Restrukturisasi manajemen perikanan tuna. Samudra Komunikasi Utama. Jakarta. $68 \mathrm{hlm}$.

Fukuda, S., B.D. Baets, W. Waegeman, J. Verwaeren, and A.M. Mouton. 2013. Habitat prediction and knowledge extraction for spawning european grayling (Thymallus thymallus L.) using a broad range of species distribution models. Environ. Model. Softw., 47:1-6. http://dx.doi.org/10. 1016/j.envsoft.2013.04.005.

Giannoulaki, M., M. Pyrounaki, B. Liorzou, L. Leonori, V.D. Valavanis, K. Tsagarakis, J.L. Bigot, D. Roos, A.D. Felice, F. Campanella, S. Somarakis, E. Arneri, and A. Machias. 2011. Habitat suitability modelling for sardine juveniles (Sardina pilchardus) in the Mediterranean Sea. Fisheries Ocean., 20:367-382. http://dx.doi.org/10.1111/j.13652419.2011.00590.

Hastie, T.J. and R. Tibshirani. 1990. Generalized additive models. London Chapman Hall. London. 352 p.

Kantun, W. dan A. Mallawa. 2015. Response of the yellowfin tuna (Thunnus albacares) on bait and depth in handline fishery of Macassart Strait. J. Perikan. (J. Fish. Sci.), 17(1):1-9.
Wilayah perairan yang potensial di musim barat terdapat pada perairan Pulau Siberut dan Sipora sementara pada musim timur lebih potensial pada perairan Pulau Siberut, Sipora, Pagai Utara dan Pagai Selatan.

Lima, A.C., C.E.C. Freitas, M.A.P. Abuabara, M. Petrere, and V.S. Batista. 2000. On the standardization of the fishing effort. Acta Amaz., 30(1):167-169.

Martono, Halimurrahman, R. Komarudin, Syarief, S. Priyanto, dan D. Nugraha. 2008. Studi variabilitas lapisan atas perairan Samudera Hindia berbasis model laut. Surabaya. $7 \mathrm{hlm}$.

Nontji, A. 1987. Laut nusantara. Djambatan. Jakarta. 368 hlm.

Nugraha, B. dan Hufiadi. Produktivitas perikanan tuna longline di Benoa. Marine Fisheries, 3(2):135-140.

Nurdin, S., M.A. Mustapha, T. Lihan, and M. Zainuddin. 2017. Applicability of remote sensing oceanographic data in the detection of potential fishing grounds of Rastrelliger kanagurta in the archipelagic waters of Spermonde, Indonesia. Fish. Res., 196:1-12. http://dx.doi.org/10.1016/ j.fishres.2017.07.029.

Pamungkas, W. 2012. Aktivitas osmoregulasi, respons pertumbuhan dan energetic cost pada ikan yang dipelihara dalam lingkungan bersalinitas. Media Akuakultur, 7(1):4451.

Parson, R.T., M. Takeshi, and B. Hargrave. 2013. Biological oceanography process. Elsevier. Bedford Institute, UK. 157 p.

Pelabuhan Perikanan Samudera Bungus (PPS Bungus). 2016. Statistik perikanan tangkap pelabuhan samudera bungus. PPSB. Pro. Sumatera Barat. $136 \mathrm{hlm}$.

Petrere, J., H.C. Giacomini, and D. Marco. 2010. Catch-per-unit-effort: which estimator is best. Braz. J. Biol., 
70:483-491.

Rajapaksha, J.K., T. Nishida, and L. Samarakoon. 2010. Environmental preferences of yellowfin tuna (Thunnus albacores) in the northeast Indian Ocean: an application of remote sensing data to longline catches. 5-7.

Saitoh, K. and S. Saitoh. 2008. Prediction of sardine fishing ground as determined by multi-sensor remote sensing and gis. Int. J. Remote Sens. Earth Sci., 5:67-83.

Siregar, V. dan Hariyadi. 2011. Identifikasi parameter oseanografi utama untuk penentuan daerah penangkapan ikan lemuru dengan menggunakan citra satelit modis di perairan Selat Bali. $J$. Akuatik, 1(1):32 - 38.

Solanki, H.U., D. Bhatpuria, and P. Chauhan. 2016. Applications of generalized additive model (gam) to satellitederived variables and fishery data for prediction of fishery resources distributions in the Arabian Sea. Geocarto Int., 6049 (April). http://dx.doi.org/10.1080/10106049.2 015.1120357.

Sukresno, B., A. Hartoko, B. Sulistyo, and Subiyanto. 2015. Empirical cumulative distribution function (ecdf) analysis of Thunnus sp. using argo float sub-surface multilayer temperature data in Indian Ocean South of Java. Procedia Environ. Sci., 23:358-367. http://dx.doi.org/10.1016 /j.proenv.2015.01.052.

Supadiningsih, C. and R. Nurul. 2004. Penentuan fishing ground tuna dan cakalang dengan teknologi penginderaan jauh. Pertemuan Ilmiah Tahunan I. Teknik Geodesi Institut Teknologi Sepuluh November. Surabaya. $16 \mathrm{hlm}$.

Susanto, R.D., Gordon, and Zheng. 2001. Upwelling along the coasts of java and sumatra and its relation to ENSO. Geophys. Res. Lett., 28/8:1599-1602.
Susilo, E. dan T.A. Wibawa. 2017. Pemanfaatan data satelit oseanografi untuk memprediksi daerah penangkapan ikan lemuru berbasis rantai makanan dan pendekatan statistik gam. J. Kelauatan Naional, 11(2): 77-87.

Valavanis, V.D., G.J. Pierce, A.F. Zuur, A. Palialexis, A. Saveliev, I. Katara, and J. Wang. 2008. Modelling of essential fish habitat based on remote sensing, spatial analysis and gis. Hydrobiologia, 612:5-20. http://dx.doi.org/ 10.1007/s10750-008-9493.

Wibawa, T.A. 2011. Prediksi sebaran daerah potensial penangkapan tuna mata besar dengan data satelit oseanografi, argo float, model statistika dan gis. Makalah disajikan dalam Seminar kelautan internasional, Universitas Udayana, 9 Juni 2011. Balai Penelitian dan Observasi Laut, Denpasar.

Wibawa, T.A. 2012. Pemanfaatan data harian sensor modis aqua/terra untuk memperkirakan sebaran kelimpahan diatom di Selat Bali. J. Kelautan Nasional, 7(2):120-132.

Wood, S.N. 2006. Generalized additive models: an introduction with R. $J$. Statis. Soft., 16:1-12.

Yen, K.W., H.J. Lu, Y. Chang, and M.A. Lee. 2012. Using remote-sensing data to detect habitat suitability for yellowfin tuna in the western and central Pacific Ocean. Int. J. Remote Sens., 33:7507-7522. http://dx.doi. org/10.1080/01431161.2012.685973.

Zainuddin, M., A. Nelwan, S.A. Farhum, Najamuddin, M.I.H. Hajar, and M. Kurnia. 2013. Characterizing potential fishing zone of skipjack tuna during the southeast monsoon in the bone bay-flores sea using remotely sensed oceanographic data. Int. J. Geosci., 4:259-266. http://dx.doi. org/10.1111/j.1365-2419.2008.00461. Zainuddin, M., K. Saitoh, and S. Saitoh. 
2008. Albacore (Thunnus alalunga) fishing ground in relation to oceanographic conditions in the western north pacific ocean using remotely sensed satellite data. Fish. Oceanogr., 17(2):61-73. http://dx. doi.org/10.1111/j.13652419.2008.00461.

Zainuddin, M., M.B. Selamat, A. Farhum, and Hidayat S. 2016. Prediction of potential fishing zones for skipjack tuna during the northwest monsoon using remotely sensed satellite data. J. Ilmu Kel., 22(2):59-66. http://dx.doi.org/10.14710/ik.ijms.22. 2.59-66.
Zuur, A., E. Ieno, and G. Smith. 2007. Analysing ecological data. SpringerVerlag. New York. 672. http://dx.doi.org/10.1007/978-0-38745972-1.

Zuur, A., E. Ieno, N. Walker, A. Saveliev, and G. Smith. 2009. Mixed effects models and extensions in ecology with R. Springer. Springer-Verlag. New York. 574. http://dx.doi.org/ 10.1007/978-0-387-87458-6.

Diterima : 02 Juli 2018

Direview : : 10 Juli 2018

Disetujui : :05 Agustus 2018 